\title{
Growth of Lactobacillus paracasei ATCC 334 in a cheese model system: A biochemical approach
}

\author{
M. F. Budinich, ${ }^{\star}$ I. Perez-Díaz, $\dagger^{1}$ H. Cai, ${ }^{\star}$ S. A. Rankin, ${ }^{*}$ J. R. Broadbent, $\ddagger$ and J. L. Steele ${ }^{\star 2}$ \\ *Department of Food Science, and \\ †Microbiology Doctoral Training Program, University of Wisconsin-Madison 53706 \\ łDepartment of Nutrition and Food Sciences, Utah State University, Logan 84322
}

\section{ABSTRACT}

Growth of Lactobacillus paracasei ATCC 334, in a cheese-ripening model system based upon a medium prepared from ripening Cheddar cheese extract (CCE) was evaluated. Lactobacillus paracasei ATCC 334 grows in $\mathrm{CCE}$ made from cheese ripened for 2 (2mCCE), 6 (6mCCE), and 8 ( $8 \mathrm{mCCE}) \mathrm{mo}$, to final cell densities of $5.9 \times 10^{8}, 1.2 \times 10^{8}$, and $2.1 \times 10^{7} \mathrm{cfu} / \mathrm{mL}$, respectively. Biochemical analysis and mass balance equations were used to determine substrate consumption patterns and products formed in $2 \mathrm{mCCE}$. The products formed included formate, acetate, and D-lactate. These data allowed us to identify the pathways likely used and to initiate metabolic flux analysis. The production of volatiles during growth of $L b$. paracasei ATCC 334 in $8 \mathrm{mCCE}$ was monitored to evaluate the metabolic pathways utilized by $L b$. paracasei during the later stages of ripening Cheddar cheese. The 2 volatiles detected at high levels were ethanol and acetate. The remaining detected volatiles are present in significantly lower amounts and likely result from amino acid, pyruvate, and acetyl-coenzyme A metabolism. Carbon balance of galactose, lactose, citrate, and phosphoserine/phosphoserine-containing peptides in terms of D-lactate, acetate, and formate are in agreement with the amounts of substrates observed in $2 \mathrm{mCCE}$; however, this was not the case for $6 \mathrm{mCCE}$ and $8 \mathrm{mCCE}$, suggesting that additional energy sources are utilized during growth of $L b$. paracasei ATCC 334 in these CCE. This study provides valuable information on the biochemistry and physiology of $L b$. paracasei ATCC 334 in ripening cheese.

Key words: nonstarter lactic acid bacteria, Lactobacillus paracasei ATCC 334, cheese model system, energy sources in cheese

Received June 22, 2009.

Accepted July 1, 2011.

${ }^{1}$ Current affiliation: US Department of Agriculture, Agricultural Research Service, Food Science Research Unit, NCSU Campus Box 7624, Raleigh, NC 27695.

${ }^{2}$ Corresponding author: jlsteele@wisc.edu

\section{INTRODUCTION}

The microbiota of ripening Cheddar cheese consists of the starter lactic acid bacteria (SLAB) and nonstarter LAB (NSLAB). Starter LAB are intentionally added to milk at the beginning of cheese manufacture, whereas NSLAB are adventitious microorganisms. The NSLAB reach levels of $10^{7}$ to $10^{8} \mathrm{cfu} / \mathrm{g}$ of cheese (Weinrichter et al., 2004) and can have a significant effect (positive or negative) on cheese flavor development (Broadbent et al., 2003). To enhance cheese quality and the consistency of cheese flavor, the dairy industry is interested in methods to control the NSLAB microbiota. However, efforts to control the NSLAB microbiota are limited by a lack of understanding of the factors that control this microbiota, in particular a detailed understanding of the substrates utilized by NSLAB for growth in cheese.

Several putative energy sources used by NSLAB to grow in ripening cheese sources have been identified, and can be divided into 2 categories: milk-derived or starter-derived substrates. Milk components include simple carbohydrates (lactose, galactose), complex carbohydrates, citrate, phosphoserine-containing peptides, fatty acids, and glycerol. Metabolic pathways for the utilization of lactose, galactose, and citrate are well characterized in NSLAB (Johnson and Steele, 2008). Complex carbohydrate-containing molecules in milk include the glycomacropeptide (GMP) derived from к-CN (Fiat et al., 1972), as well as glycoproteins and glycolipids present in the milk-fat globule membrane (MFGM; Mather, 2000; Shah, 2000). These complex carbohydrates contain galactose, $\mathrm{N}$-acetylgalactosamine, $N$-acetylglucosamine (Fiat et al., 1972; Farrar and Harrison, 1978; Neeser et al., 1991), N-acetylneuraminic acid (Martín-Sosa et al., 2003), mannose, and fucose (Kim et al., 1992). Starter-derived components are introduced into the cheese matrix largely as a consequence of starter autolysis, which results in fragmentation of the cell wall and release of ribose- and deoxyribose-containing nucleic acids. Disintegration of the cell wall is thought to enhance the bioavailability of peptidoglycan, which contains $N$-acetylglucosamine, 
and $N$-acetylmuramic acid. Thomas (1987) first demonstrated that NSLAB can grow on products from starter autolysis, but the enzymes and metabolic pathways involved in the utilization of the milk-derived complex carbohydrates, nucleic acids, and cell wall components remain unknown. However, research conducted by Adamberg et al. (2005) demonstrated that Lactobacillus paracasei strains could grow on the monosaccharide building blocks of these complex carbohydrates. Interestingly, those authors (Adamberg et al., 2005) observed that $L b$. paracasei utilized N-acetylglucosamine preferentially over lactose.

Research to determine the influence of specific nutrients or conditions on growth of NSLAB in the cheese matrix is difficult, as ripening Cheddar cheese is a complex and dynamic environment. Previous studies have employed a model cheese system based upon the use of a hydraulic press to extract the serum fraction of cheese (Hassan et al., 2004). This model system has been used to observe chemical changes in the cheese (Lee et al., 2005), and to follow bacterial growth and metabolic end-product accumulation (Díaz-Muñiz and Steele, 2006). However, this system has several disadvantages, including very low yields, long exposure time to air, temperature fluctuations, and frequent contamination problems. To overcome those limitations, we developed a Cheddar cheese extract (CCE) medium to use as a model for NSLAB growth studies. To prepare CCE, cheese is freeze-dried, then extracted with water at room temperature and filter sterilized. This approach provides good yields, limits the opportunity for contamination, and allows for better temperature control.

In this paper, we present our findings on the growth of a model NSLAB, Lb. paracasei ATCC 334, in CCE prepared from Cheddar cheese ripened for 2 (2mCCE), $6(\mathbf{6 m C C E})$, or $8(\mathbf{8 m C C E})$ mo. Additionally, the substrates utilized and the metabolic products (organic acids and volatiles) formed were evaluated.

\section{MATERIALS AND METHODS}

\section{Bacterial Strain}

Lactobacillus paracasei ATCC 334, a cheese isolate, was obtained from the American Type Culture Collection (Rockville, MD). This strain was previously called Lactobacillus casei; however, the Judicial Commission of the International Committee on Systematics of Bacteria (2008) has recently confirmed the designation of this strain as $L b$. paracasei ATCC 334 . The bacterium was maintained at $-80^{\circ} \mathrm{C}$ in lactobacilli de Man, Rogosa, and Sharpe (MRS) broth (Difco Laboratories Inc., Detroit, MI) with 10\% (vol/vol) glycerol. Working cultures were prepared from frozen stocks by 2 transfers
( $1 \% \mathrm{vol} / \mathrm{vol}$ ) in MRS broth at $37^{\circ} \mathrm{C}$ without shaking for 16 to $18 \mathrm{~h}$. Prior to conducting growth studies in other media, cells were washed twice using Dulbecco's PBS (Invitrogen Corp., Carlsbad, CA). The washed cells were held at $5^{\circ} \mathrm{C}$ and used within an hour.

\section{Cheddar Cheese Source and Composition}

Five 18-kg blocks of commercial Cheddar cheese were donated by a cheese factory from the Midwestern region of the United States and allowed to ripen at $6 \pm$ $0.5^{\circ} \mathrm{C}\left(44 \pm 2^{\circ} \mathrm{F}\right)$. The moisture content of the cheese was $39.5 \%$ and the $\mathrm{NaCl}$ content was $1.4 \%$ (wt/wt). Salt in moisture was, therefore, 3.5. The lactose, galactose, and citrate levels were determined every $2 \mathrm{wk}$ until concentrations decreased to below their minimum quantifiable levels (MQL) of 190, 220, and $20 \mu \mathrm{mol} / \mathrm{kg}$ of cheese, respectively.

\section{CCE Preparation}

Cheddar cheese extract was prepared from 2(2mCCE), 6- (6mCCE), and 8- (8mCCE) mo-old Cheddar cheese. Cheddar cheese blocks were cut into 6.35-cm cubes, shredded using a commercial food processor (AB Hällde Maskiner, Kista, Sweden), then divided into approximately 1-kg lots, and placed in plastic bags. Samples were frozen for $2 \mathrm{~h}$ at $-20^{\circ} \mathrm{C}$, and then stored at $-80^{\circ} \mathrm{C}$ until lyophilization was initiated. Lyophilization was performed for $48 \mathrm{~h}$ at $21^{\circ} \mathrm{C}$, followed by a cycle of $24 \mathrm{~h}$ at $50^{\circ} \mathrm{C}$ (Unitrap Model; Virtis Co. Inc., Gardiner, NY). The dried cheese was ground to a fine powder using a commercial food processor $(\mathrm{AB}$ Hällde Maskiner) and stored in sealed plastic bags at $5^{\circ} \mathrm{C}$ until extracted. The following sequential extraction procedure was followed: $500 \mathrm{~g}$ of the powdered cheese was mixed with $2 \mathrm{~L}$ of cold sterile distilled water in a commercial blender (Waring Products Division, New Hartford, CT) for $10 \mathrm{~min}$ at low speed. The filtrate was cooled in an ice bath for $10 \mathrm{~min}$, and the liquid/ solid mixture percolated through cheesecloth to remove solids. The subsequent filtrate was reused to extract 6 further 500-g amounts of cheese to finally obtain an extract made from $3 \mathrm{~kg}$ of solids in $2 \mathrm{~L}$ of water (ratio of 6 parts of dried cheese to 4 parts of water), which was based on the moisture content of the original cheese. Hence, $18.14 \mathrm{~kg}$ (40 lbs) of cheese with a moisture content of $40 \%$ yields $7.25 \mathrm{~kg}$ (16 lbs) of CCE. Subsequently, 2-L extracts were aliquoted into 200-mL centrifuge tubes (Nalgene Nunc International Corp., Rochester, $\mathrm{NY}$ ), cooled in an ice bath for $10 \mathrm{~min}$, and centrifuged for 10 min at $9,000 \times g$ at $5^{\circ} \mathrm{C}$ (Beckman Instruments Inc., Arlington Heights, IL). The supernatant, now referred to as $\mathrm{CCE}$, was transferred into 2-L plastic 
bottles and stored at $-20^{\circ} \mathrm{C}$. Cheddar cheese extracts were thawed in a $37^{\circ} \mathrm{C}$ water bath (Precision Scientific Inc., Chicago, IL), and centrifuged for $20 \mathrm{~min}$ at 22,000 $\times g$ at $5^{\circ} \mathrm{C}$ to remove fine solids. After centrifugation, CCE was sequentially filtered through a $0.7-\mu \mathrm{m}$ TCLP filter (Fisher, Fair Lawn, NJ) and a 0.2- $\mu$ m PES filter (Nalgene Nunc International Corp.) to achieve sterility. The filtered CCE were mixed and re-filtered into a sterile 2.5 -L bottle with a $0.2-\mu \mathrm{m}$ bottle top filter, then stored at $-20^{\circ} \mathrm{C}$ until needed.

\section{Fermentation Studies}

Batch fermentations were conducted in a 2.5-L autoclaved fermentation vessel (BioFlo III; New Brunswick Scientific Co. Inc., Edison, NJ) containing $2.2 \mathrm{~L}$ of filter-sterilized CCE. The redox of CCE was adjusted to $+250 \mathrm{mV}$ (redox potential, $\mathbf{E}_{\mathrm{h}}$ ) by flushing with a $95 \% \mathrm{~N}_{2}$ and $5 \% \mathrm{CO}_{2}$ gas mix (Linde Gas LLC, Madison, WI) at $0.5 \mathrm{~L}$ per minute because previous work had shown this step was necessary for growth of $L b$. paracasei ATCC 334 in this medium (our unpublished data). The fermentation vessel was inoculated with $0.01 \% \mathrm{vol} / \mathrm{vol}$ of a washed suspension of $L b$. paracasei ATCC 334 standardized to an optical density at 600 $\mathrm{nm}\left(\mathrm{OD}_{600}\right)$ of 0.1 , to achieve a cell density of $10^{3} \mathrm{cfu} /$ $\mathrm{mL}$, and then incubated at $37^{\circ} \mathrm{C}$ until the stationary phase was reached. The $\mathrm{pH}$ was maintained at 5.2 using the BioFlo III control system (New Brunswick Scientific Co. Inc.) and a pH controller (model 200; Eutech Instruments Pte. Ltd., Vernon Hills, IL) via the automatic addition of either $250 \mathrm{mM} \mathrm{HCl}$ or $\mathrm{NaOH}$. Autoclavable probes were used to monitor $\mathrm{pH}$, redox $(\mathrm{Ag} / \mathrm{AgCl} 4 \mathrm{M} \mathrm{KCl}$; Mettler-Toledo, Columbus, $\mathrm{OH})$, and dissolved oxygen (polarographic electrode from Phoenix Electrode Co., Houston, TX). During fermentations, the vessel was continuously purged with filtered sterile $(0.1 \mu \mathrm{m})$ anaerobic gas mix $\left(95 \% \mathrm{~N}_{2}, 5 \% \mathrm{CO}_{2}\right)$ at $0.1 \mathrm{~L}$ per minute and the agitation rate was set at $50 \mathrm{rpm}$. A 20-mL sample was collected every $4 \mathrm{~h}$, serial decimal dilutions were made and appropriate dilutions were spread plated on MRS agar in triplicate, followed by anaerobic incubation at $37^{\circ} \mathrm{C}$ for $48 \mathrm{~h}$. Changes in dissolved oxygen and redox potential were monitored continuously using an Electronic Signal Data Logger ES120 Dickson (A. Daigger \& Co. Inc., Vernon Hills, IL). The remainder of the $20-\mathrm{mL}$ sample was filtersterilized using a $0.2-\mu \mathrm{m}$ filter (Nalgene) and frozen at $-80^{\circ} \mathrm{C}$. These samples were subsequently analyzed for simple carbohydrates (galactose, lactose), citrate, phosphopeptides, formate, acetate, L-lactate, D-lactate, and volatile compounds.

\section{Chemical Analysis of Carbohydrates and Organic Acids}

Lactose, galactose, citrate, D/L lactate, formate, acetate, and ethanol concentrations were determined using commercial enzymatic detection kits from R-Biopharm Inc. (Marshall, MI). The kits were used as directed by the supplier except that the total volume of the assay was decreased from $3 \mathrm{~mL}$ to $600 \mu \mathrm{L}$, while maintaining the proportions described in the manufacturer's instructions.

\section{Analysis of Phosphoserine-Containing Peptides}

A checkerboard ELISA (Harlow and Lane, 1988) was initially used to determine the optimum combination of antibody and solid-phase substrate needed for analysis of phosphoserine peptides, and then an indirect competitive ELISA with anti-phosphoserine monoclonal antibody was developed to measure both free and peptide-bound phosphoserine. The checkerboard ELISA was performed with a $1 \mathrm{mg} / \mathrm{mL}$ initial concentration of O-phospho-L-serine conjugated to BSA (Sigma-Aldrich, St. Louis, MO) that was diluted 1/5 across the rows of a 96-well plate with 1/10 dilutions of a 1/4,000 monoclonal antibody (Mab; Sigma-Aldrich) across the columns to identify the antigen-Mab combination that gave an absorbance at $405 \mathrm{~nm}\left(\mathrm{~A}_{405}\right)$ of 1.0. The concentration was determined to be $1 \mu \mathrm{g} / \mathrm{mL}$ of O-phospho-L-serine-BSA (Sigma-Aldrich), and a Mab dilution of $1 / 40,000$.

The inhibitor solution was coated in an HB Costar 96-well plate at $1 \mathrm{ug} / \mathrm{mL}$ in a $100 \mathrm{~m} M$ carbonate buffer $\left(\mathrm{pH}\right.$ 9.6) for $20 \mathrm{~h}$ at $5^{\circ} \mathrm{C}$, and then the plate was washed with PBS and incubated with $1 \mathrm{mg} / \mathrm{mL}$ of BSA (Sigma-Aldrich) for $2 \mathrm{~h}$ with gentle horizontal shaking to block unused binding sites. An indirect ELISA was then performed as follows: a standard curve of 0.5 to $10 \mathrm{mM}$ O-phospho-L-serine (Sigma-Aldrich) was prepared in PBS, and then $90 \mu \mathrm{L}$ of each sample and standard was added to the plate. Next, $90 \mu \mathrm{L}$ of Mab in PBST was added to each well and allowed to react for $2 \mathrm{~h}$ at $21^{\circ} \mathrm{C}$ before $180 \mu \mathrm{L}$ of anti-goat anti-mouse antibody, coupled with peroxidase (Thermo Fisher Scientific, Rockford, IL), was added and incubated for $2 \mathrm{~h}$ at $21^{\circ} \mathrm{C}$. After this period, the conjugate solution was discarded and plates were washed 5 times using PBST. Wells were filled with $100 \mu \mathrm{L}$ of substrate solution that contained $1.0 \mathrm{mM} 2,2^{\prime}$-azino-bis-(3-ethylben-

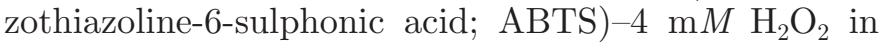
$50 \mathrm{~m} M$ sodium citrate $(\mathrm{pH} 4.0)$ and the plates were shaken at $25^{\circ} \mathrm{C}$ for $30 \mathrm{~min}$ in the dark. The plates were 
read at $405 \mathrm{~nm}$ in a microplate reader (Bio-Rad 680m; Bio-Rad Laboratories Inc., Hercules, CA) and the data were analyzed using SoftMax Pro software version 4 for Microsoft Windows XP (Molecular Devices Inc., Sunnyvale, CA). The detection limit for this analysis was $0.1 \mathrm{mEq}$ of O-phospho-L-serine.

\section{Volatiles Analysis}

The volatiles produced in CCE fermentation experiments were analyzed using solid-phase microextraction with a Carboxen/polydimethylsiloxane fiber (Supelco Inc., Bellefonte, PA) and analyzed by GC-MS as described previously (Rankin et al., 1998; Rankin, 2001).

\section{Kinetic Analysis}

For microbial batch cultures, the Gompertz model (Equation 1) is one of the most suitable in terms of interpretability, ease of use, and fit to growth data (Zwietering et al., 1990):

$$
y=A \times \exp \left\{-\exp \left[\frac{\mu_{\max } \times e}{A}(\lambda-t)+1\right]\right\},
$$

where $y$ represents cell numbers $/ \mathrm{mL} ; \lambda$ is the lag time; $A$ is the maximum cell number $/ \mathrm{mL} ; \mu_{\max }$ is the maximum growth rate; $e$ is the $\exp (1)$; and $t$ is time. The generation time $\left(g_{t}\right)$ can be calculated by mathematical transformation of $\mu_{\max }$.

The apparent maximum substrate consumption rate could be expressed using a modified Gompertz model, as described by Fan et al. (2004):

$$
S_{0}-S=S_{\max } \times \exp \left\{-\exp \left[\left(\frac{R_{\text {max }, S} \times e}{S_{\max }}\right) \times(\lambda-t)+1\right]\right\},
$$

where $S$ represents the substrate concentration; $S_{0}$ the initial substrate concentration; $S_{\max }$ is the final substrate concentration; $R_{\max , S}$ is the apparent maximum substrate consumption rate; $e$ is the $\exp (1) ; t$ is time; and $\lambda$ is the time at which the substrate begins to be consumed at $R_{\max , S}$.

By differentiating Equation 2, the apparent rate of substrate consumption $\left(-r_{S}\right)$ was described as

$$
-r_{S}=R_{\max , S} \times \exp \left\{\begin{array}{l}
-\exp \left[\left(\frac{R_{\text {max }, S} \times e}{S_{\max }}\right) \times(\lambda-t)+1\right] \\
+\left[\left(\frac{R_{\text {max }, S} \times e}{S_{\max }}\right) \times(\lambda-t)+1\right]+1
\end{array}\right\} \cdot[3]
$$

Similarly to substrate consumption and bacterial growth, the formation of aqueous products was analyzed using the following equations derived from the Gompertz model:

$$
P_{i}=\Delta P_{\max , i} \times \exp \left\{-\exp \left[\left(\frac{R_{\text {max }, P_{i}} \times e}{\Delta P_{\max , i}}\right) \times(\lambda-t)+1\right]\right\},[4]
$$

where $P$ represents the product concentration; $\Delta P_{\max , i}$ is the maximum product concentration; $R_{\max , P_{i}}$ is the apparent maximum product formation rate; and $\lambda$ is the time at which the product begins to be formed at $R_{\max , P_{i}}$.

By differentiating Equation 4, the apparent formation rate of products $\left(r_{P}\right)$ can be expressed as

$$
r_{P_{i}}=R_{\max , P_{i}} \times \exp \left\{\begin{array}{l}
-\exp \left[\left(\frac{R_{\text {max }, P_{i}} \times e}{\Delta P_{\max , i}}\right) \times(\lambda-t)+1\right] \\
\left.+\left[\left(\frac{R_{\text {max }, P_{i}} \times e}{\Delta P_{\text {max }, i}}\right) \times(\lambda-t)+1\right]+1\right]
\end{array}\right\} \cdot[5]
$$

These equations (Eq. 2 to Eq. 5) are independent of biomass formation; hence, they determine an apparent maximum rate. However, because we are conducting a batch fermentation, we also need to calculate the specific substrate consumption rate $\left(q_{s_{i}}\right)$, which was determined using the logarithmic method (Görgens et al., 2005):

$$
q_{s_{i}}=\exp \left(\frac{\Delta \ln \left(\frac{S_{i}}{N-N_{0}}\right)}{\Delta t}\right),
$$

where $S_{i}$ is the total amount of substrate used in picomoles; $N_{0}$ and $N$ are the biomass expressed as total colony-forming units at the beginning of fermentation and at a specific time, respectively; and $\Delta t$ is the change in time between substrate and biomass measurements. During exponential growth, the specific substrate consumption rate remains constant and is estimated by nonlinear regression.

\section{Statistical Analyses}

All of the CCE experiments described in this paper were performed in triplicate, requiring a total of 9 fermentations. During each growth experiment a sample was taken every $4 \mathrm{~h}$, with a minimum of 12 samples per 
fermentation. Enumeration was done in triplicate and log-transformed before applying nonlinear regression to obtain Gompertz growth parameters. To determine if the parameters obtained from the nonlinear regression fitting to the Gompertz model accurately described the data, ANOVA and lack of fit test analyses were conducted (data not shown). The determination of products and substrates was done in duplicate analysis of triplicate samples and submitted to the same statistical analysis as bacterial enumeration. Statistical analysis and model fitting for both apparent maximum consumption rate and specific substrate consumption rate were done using SAS software, version 9.1.3 of the SAS System for Microsoft Windows XP (SAS Institute Inc., Cary, NC). Curve model fitting was done using Table Curve 2D, version 5.02 of Microsoft for Windows XP (Systat Software Inc., San Jose, CA).

\section{RESULTS AND DISCUSSION}

\section{Cheese Composition}

After 2 mo of ripening, the Cheddar cheese contained $1.70 \pm 0.13 \mu \mathrm{mol}$ of lactose $/ \mathrm{kg}, 2.83 \pm 0.09 \mu \mathrm{mol}$ of galactose $/ \mathrm{kg}$, and $2.91 \pm 0.42 \mu \mathrm{mol}$ of citrate $/ \mathrm{kg}$. After $4 \mathrm{mo}$, the cheese contained $0.58 \pm 0.01 \mu \mathrm{mol}$ of lactose $/ \mathrm{kg}, 1.40 \pm 0.09 \mu \mathrm{mol}$ of galactose $/ \mathrm{kg}$, and $2.3 \pm$ $0.13 \mu \mathrm{mol}$ of citrate $/ \mathrm{kg}$. After 6 and $8 \mathrm{mo}$ of ripening, the levels of lactose, galactose, and citrate were below the quantifiable limit (BQL), most likely due to the metabolic activity of the cheese microbiota. The total lactic acid concentration was determined to be $36.2 \pm$ 2.56, $28.2 \pm 1.70$, and $29.4 \pm 1.04 \mu \mathrm{mol} / \mathrm{kg}$ in Cheddar cheese ripened for 2,6 , and 8 mo, respectively. The observed net decrease of $8.0 \pm 3.08 \mu \mathrm{mol}$ of total lactic acid $/ \mathrm{kg}$ between 2 and 6 mo of ripening was likely due to its utilization by the cheese microbiota.

\section{Growth Parameters}

To study NSLAB metabolism in cheese, we developed $\mathrm{CCE}$ as a model growth medium. Many models have been developed to describe microbial growth (Zwietering et al., 1990). For microbial batch cultures, such as in these experiments, the Gompertz model (Equation 1 ) has greatest utility.

The growth of $L b$. paracasei ATCC 334 in $2 \mathrm{mCCE}$, $6 \mathrm{mCCE}$, and $8 \mathrm{mCCE}$ at $37^{\circ} \mathrm{C}$ and $\mathrm{pH} 5.2$ is presented in Figure 1. Interestingly, slight inflections were noted in each of the curves, which may indicate a diauxic-like growth of $L b$. paracasei ATCC 334 in CCE. Growth kinetic parameters of $L b$. paracasei ATCC 334 in $2 \mathrm{mCCE}$, $6 \mathrm{mCCE}$, and $8 \mathrm{mCCE}$ at $37^{\circ} \mathrm{C}$ and $\mathrm{pH} 5.2$ are presented in Table 1. All of the kinetic parameters obtained from the Gompertz model $\left(\mu_{\max }, \lambda\right.$, and $A$ ) were statistically significant and necessary, as determined by nonlinear regression analysis, to describe the growth data for each CCE used $(P<0.001)$. Individual ANOVA analysis of each of these parameters from the different $\mathrm{CCE}$ indicated that the duration of the lag phase was not significantly different $(P>0.05)$. However, differences in maximum growth rates and final cell densities were statistically significant $(P<0.01)$ for $2 \mathrm{mCCE}$, $4 \mathrm{mCCE}$, and 8mCCE. Lactobacillus paracasei ATCC 334 reached $5.9 \times 10^{8}, 1.2 \times 10^{8}$, and $2.1 \times 10^{7} \mathrm{cfu} / \mathrm{mL}$ in $2 \mathrm{mCCE}, 6 \mathrm{mCCE}$, and $8 \mathrm{mCCE}$, respectively. These cell densities are equivalent to $2.4 \times 10^{8}, 4.8 \times 10^{7}$, and $8.4 \times 10^{6} \mathrm{cfu} / \mathrm{g}$ of cheese and are within the range $(5$ $\times 10^{6}$ to $\left.1 \times 10^{9} \mathrm{cfu} / \mathrm{g}\right)$ typically observed in ripening Cheddar cheese (Johnson et al., 1990; Broadbent et al., 2003). The ability of $L b$. paracasei ATCC 334 to reach these cell densities in $6 \mathrm{mCCE}$ might still be explained by assuming concentrations at or close to the BQL of our analytical determination of lactose, galactose, and citrate. The cell densities reached at $8 \mathrm{mCCE}$ may also be explained by assuming a value as low as $1 / 10$ of the BQL concentration as described by the work, under anaerobic conditions of Escherichia coli, of Lendenmann and Egli (1998). However, these assumptions require a very low maintenance coefficient $(m$; van Bodegom, 2007 ) and a very high efficiency of energy conversion $\left(\mathrm{Y}_{\mathrm{ATP} / \text { hexose }}\right)$, as well as high biomass conversion $\left(\mathrm{Y}_{\text {bio- }}\right.$ mass/ATP; Adamberg et al., 2003). The combination of all of these properties in batch fermentation is highly unlikely. Therefore, we hypothesize that alternative energy sources are utilized by Lb. paracasei ATCC 334 to reach these cell densities. Strong evidence favoring this hypothesis is that these low values of lactose, galactose, and citrate are not sufficient to account for the quantity of formate and acetate produced (Table 2). Maximum growth rates decreased as the age of the Cheddar cheese used to prepare the CCE increased, which indicated that many readily utilized or energetically favorable substrates had been utilized before the $\mathrm{CCE}$ was prepared. However, it is important to note that even after 8 mo of ripening, Cheddar cheese contains sufficient nutrients to support the growth of $L b$. paracasei ATCC 334 to final densities of greater than $10^{6} \mathrm{cfu} / \mathrm{g}$ of cheese. These results suggest that growth of NSLAB in Cheddar cheese aged for 8 mo is not impeded by nutrient depletion.

\section{Redox Potential and Dissolved Oxygen}

In bacterial ripened cheeses such as Gouda or Cheddar, the $\mathrm{E}_{\mathrm{h}}$ decreases to levels lower than $-130 \mathrm{mV}$ during the first month of ripening due to SLAB metabolism (Galesloot, 1960; Galesloot and Kooy, 1960). 
Table 1. Growth kinetics ${ }^{1}$ of Lactobacillus paracasei ATCC 334 at $37^{\circ} \mathrm{C}$ and $\mathrm{pH} 5.2$ in Cheddar cheese extract prepared from 2-, 6-, and 8-moold cheese ${ }^{2}$

\begin{tabular}{|c|c|c|c|c|c|c|}
\hline Model parameter ${ }^{3}$ & \multicolumn{6}{|c|}{ Cheddar cheese extract } \\
\hline Maximum growth rate $\left[\mu_{\max }\left(\mathrm{h}^{-1}\right)\right]^{4}$ & 0.34 & 0.022 & 0.26 & 0.033 & 0.21 & 0.028 \\
\hline Doubling time $\left[\mathrm{g}_{\mathrm{t}}(\min )\right]^{5}$ & 53 & 4.1 & 69 & 7.2 & 88 & 6.1 \\
\hline Final $\mathrm{cfu} / \mathrm{mL}$ & \multicolumn{2}{|c|}{$5.9 \times 10^{8}$} & \multicolumn{2}{|c|}{$1.2 \times 10^{8}$} & \multicolumn{2}{|c|}{$2.1 \times 10^{7}$} \\
\hline
\end{tabular}

${ }^{1}$ Kinetic constants were calculated using an equation derived from the Gompertz model (Zwietering et al., 1990).

${ }^{2}$ Results represent the mean derived from triplicate experiments.

${ }^{3}$ Nonlinear regression model fit was statistically significant at $P<0.0001$ for all 3 growth experiments.

${ }^{4}$ Analysis of variance of growth rate showed a statistically significant difference at $P<0.05$ for all 3 growth experiments.

${ }^{5}$ Calculated using $\mu_{\max }$ values.

Changes in redox and dissolved oxygen during growth of $L b$. paracasei ATCC 334 in $2 \mathrm{mCCE}$ are presented in Figure 2. Redox values decreased from $\mathrm{E}_{\mathrm{h}}+250$ to $-140 \mathrm{mV}$ during growth, with the most rapid decrease during logarithmic growth. A slight increase in redox was observed at the end of fermentation, suggesting that the ability of $L b$. paracasei ATCC 334 to maintain a low redox in its environment decreases in the stationary phase. Dissolved oxygen remained constant at approximately $1.1 \mu M$ during the fermentation. Similar patterns were observed in $L b$. paracasei ATCC 334 fermentations in CCE prepared from 6- and 8-mo-old Cheddar cheese (data not shown).

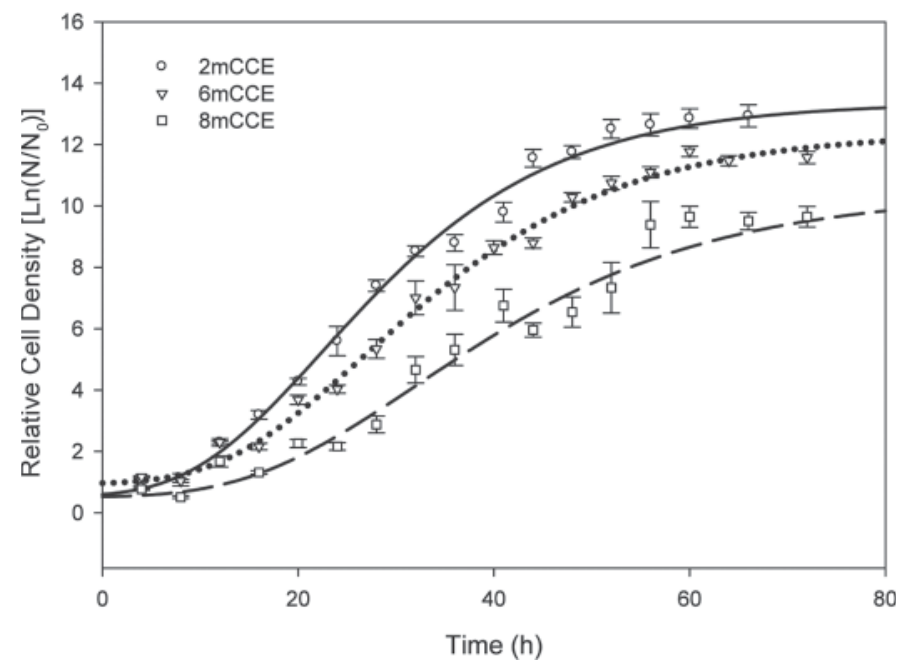

Figure 1. Growth of Lactobacillus paracasei ATCC 334 at $37^{\circ} \mathrm{C}$ and $\mathrm{pH} 5.2$ in Cheddar cheese extract prepared from 2- (O), 6- $(\nabla)$, and 8- ( $\square$ ) mo-old cheeses (2mCCE, 6mCCE, and 8mCCE, respectively). Nonlinear regression fit lines for relative cell density during growth in Cheddar cheese extracts prepared from 2- $(-), 6-(\cdots)$, and 8- $(--)$ mo-old cheeses were obtained using the Gompertz growth model. $\mathrm{N}$ / $\mathrm{N}_{0}=$ relative population size. Bars represent the standard deviation of triplicate experiments and triplicate platings.
Modification of cheese redox potential is one mechanism by which microorganisms influence cheese flavor development. Traditionally this role was attributed to the SLAB (Galesloot, 1960). However, the use of adjuvant NSLAB at the beginning of the fermentation may result in this role being shared by SLAB and NSLAB (Swearingen et al., 2001). During growth in CCE, $L b$. paracasei ATCC 334 was observed to reduce the environment, most likely by altering the $\mathrm{NAD}+/ \mathrm{NADH}$ equilibrium toward an excess NAD + pool (Fernández and Zuniga, 2006). Common metabolic strategies of lactobacilli to regenerate NADH include conversion of pyruvate to ethanol or organic acids, and metabolism of AA (Axelsson, 2004; Fernández and Zuniga, 2006). In addition to influencing the $\mathrm{NAD}+/ \mathrm{NADH}$ equilibrium, these pathways lead to the formation of compounds that result in cheese flavor development (Kieronczyk et al., 2001; Mauriello et al., 2001). Cheese redox potential also influences chemical reactions in the matrix (Kristoffersen, 1967). For example, methionine and cysteine catabolism yield precursors of Cheddar cheese sulfur flavor compounds, which are essential for typical Cheddar cheese flavor (Singh et al., 2003), and whose stability is dependent on the redox and oxygen level in the cheese matrix; hence, further chemical and enzymatic reactions involving these precursors is dependent on the cheese redox potential. Consequently, the redox affects both the metabolic pathways that lead to the formation of cheese flavor compounds and their stability (Seefeldt and Weimer, 2000; Marilley and Casey, 2004).

\section{Kinetics of Lactose, Galactose, and Citrate Utilization}

Initial concentrations of lactose, galactose, and citric acid in $2 \mathrm{mCCE}$ were $1.69 \pm 0.13 \mathrm{mM}, 2.83 \pm 0.09$ $\mathrm{m} M$, and $2.91 \pm 0.42 \mathrm{~m} M$, respectively. Lactose, ga- 


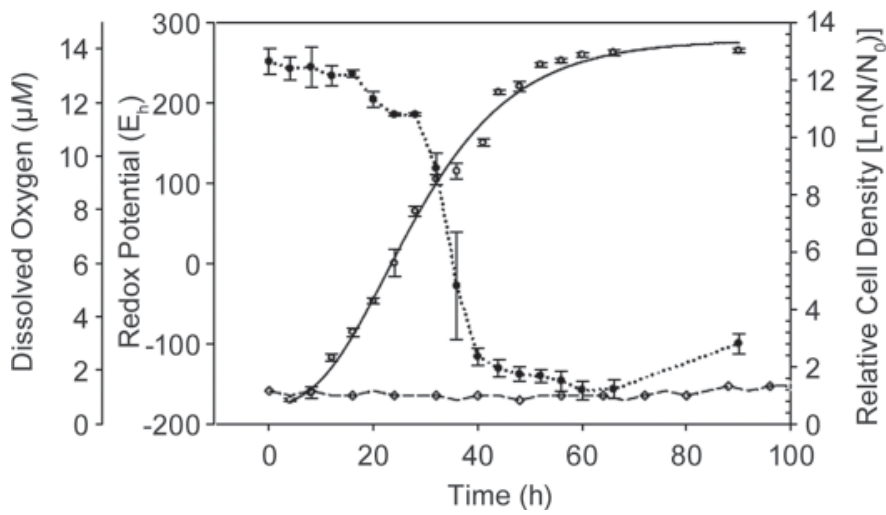

Figure 2. Changes in relative cell density $(\bigcirc)$, redox potential $(\cdot \bullet \cdot \cdot)$, and dissolved oxygen $\left(-\nabla_{-}\right)$during growth of Lactobacillus paracasei ATCC 334 at $37^{\circ} \mathrm{C}$ and $\mathrm{pH} 5.2$ in Cheddar cheese extract prepared from 2-mo-old cheese. Nonlinear regression fit line for relative cell density (-) during growth was obtained using the Gompertz growth model. $\mathrm{N} / \mathrm{N}_{0}=$ relative population size. Bars represent the standard deviation of triplicate experiments and duplicate analysis. lactose, and citric acid consumption during growth of Lb. paracasei ATCC 334 in $2 \mathrm{mCCE}$ are presented in Figure 3. It is interesting to note that none of the substrates examined showed an apparent decrease during exponential growth. This observation can be explained either by highly efficient conversion of these substrates to biomass (Zeng and Deckwer, 1995) or utilization of a substrate present in CCE, but not measured in the current analysis. It can also be explained by the use of multiple concurrent substrates at very low concentrations (Kovárová-Kovar and Egli, 1998). Testing these hypotheses was beyond the scope of the current study.

Analysis of variance of lag time duration $(\lambda)$ for lactose, galactose, and citrate, indicated that lactose was the first of these compounds to be utilized at its apparent maximum consumption rate $\left(\mathrm{R}_{\text {max Lac }} ; P<0.05\right.$; Table 3). However, no statistical difference was observed for galactose and citrate, although the apparent maximum consumption rate for citrate was observed earlier than for galactose. Lactose utilization occurred during late logarithmic growth and was utilized at an apparent

Table 2. Kinetics for fermentation products produced by Lactobacillus paracasei ATCC 334 at $37^{\circ} \mathrm{C}$ and $\mathrm{pH} 5.2$ during growth in Cheddar cheese extract (CCE) prepared from 2-, 6-, and 8-mo-old cheese ${ }^{1}$

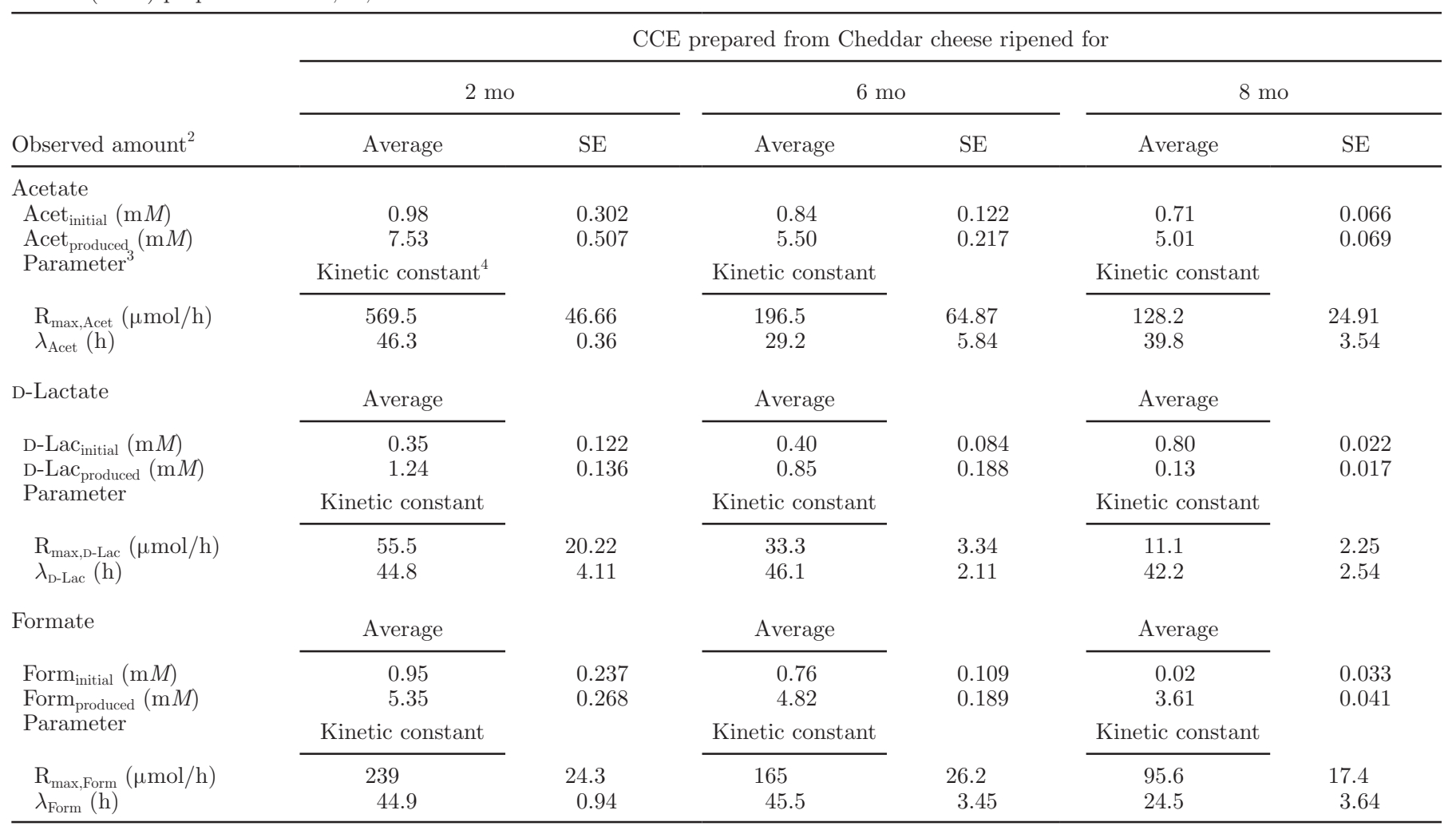

${ }^{1}$ Results represent the mean derived from triplicate experiments.

${ }^{2}$ Initial and produced product concentrations for acetate, D-lactate, and formate are designated by Acet initial $_{\text {, D-Lac }}$ initial, Form initial $_{\text {, Acet }}$ produced, D-Lac produced $_{\text {, and Form }}$ produced, respectively.

${ }^{3}$ Maximum production rates of acetate, D-lactate, and formate are designated as $\mathrm{R}_{\max , A c e t}, \mathrm{R}_{\max , \mathrm{D}-\mathrm{Lac}}$, and $\mathrm{R}_{\max , F o r m}$, respectively. The time when acetate, D-lactate, and formate formation are being observed are designated by $\lambda_{\text {Acet }}, \lambda_{\text {D-Lac }}$, and $\lambda_{\text {Form }}$, respectively.

${ }^{4}$ Kinetic constants were calculated using an equation derived from the Gompertz equation (Fan et al., 2004). Estimates are statistically significant at $\alpha=0.05$. 

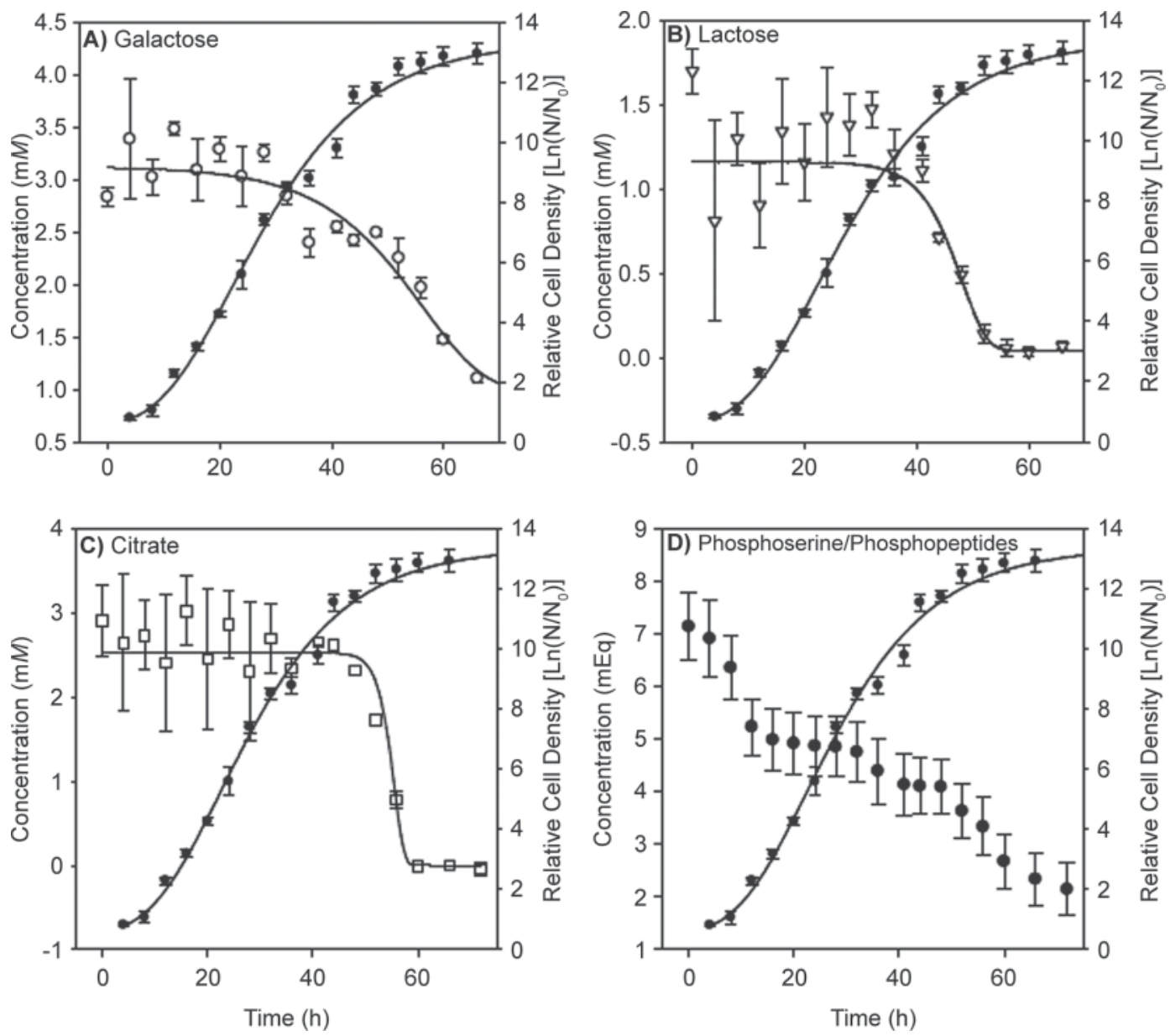

Figure 3. Changes in galactose $(\bigcirc)$, lactose $(\nabla)$, citrate $(\square)$, and phosphopeptide (large solid circles) concentrations in Cheddar cheese extract during growth of Lactobacillus paracasei ATCC $334(\bullet)$ at $37^{\circ} \mathrm{C}$ and pH 5.2 in Cheddar cheese extract prepared from 2-mo-old cheese. N/ $\mathrm{N}_{0}=$ relative population size. Bars represent the standard deviation of triplicate experiments and duplicate analysis.

maximum rate $\left(\mathrm{R}_{\text {max,Lac }}\right)$ of $109 \pm 21.9 \mu \mathrm{mol} / \mathrm{h}$, presumably even at concentrations below the limit of detection. Lactose utilization occurred without a detectable increase in galactose concentration, indicating that the glucose and galactose moieties were metabolized concurrently. This outcome was expected because although genes for phosphoenolpyruvate-dependent lactose phosphotransferase and $\beta$-galactosidase/lactose permease systems are both present in the $L b$. paracasei ATCC 334 genome, this organism does not possess an annotated gene with the lactose-galactose antiport function, such as lactose permease (LacS) described by Foucaud and Poolman (1992) in Streptococcus thermophilus.

Statistically, apparent maximum rates of galactose and citrate began at the same time $(P=0.226)$, suggesting these substrates may be co-metabolized, with the galactose apparent maximum consumption rate being approximately one-half that of citrate $(98 \pm 28.3$ vs. $171 \pm 29.7 \mu \mathrm{mol} / \mathrm{h}$, respectively). These results are consistent with previous reports indicating that galactose and citrate are co-utilized during growth in cheese serum (Díaz-Muñiz and Steele, 2006). The most probable pathway for citrate utilization in ripening Cheddar cheese by $L b$. paracasei ATCC 334 is citrate to oxaloacetate and acetate, and oxaloacetate to pyruvate and $\mathrm{CO}_{2}$, with these steps catalyzed by citrate lyase and a membrane-bound oxaloacetate decarboxylase (Díaz-Muñiz et al., 2006). The resulting pyruvate pool would subsequently be metabolized by one of several competing pathways (Supplemental Figure S1, available online at http://www.journalofdairyscience.org), depending on the cell's physiological needs. Citrate levels fell to BQL between late logarithmic growth and early stationary phase, whereas detectable levels of residual galactose were still present at the end of the fermentation.

The specific consumption rates were estimated using Equation 6 and a nonlinear regression fit. These were 
Table 3. Kinetics of substrate consumption for galactose, lactose, and citrate during fermentation by Lactobacillus paracasei ATCC 334 at $37^{\circ} \mathrm{C}$ and $\mathrm{pH} 5.2$ in Cheddar cheese extract prepared from 2-mo-old cheese $^{1}$

\begin{tabular}{|c|c|c|}
\hline Parameter $^{2}$ & $\begin{array}{l}\text { Kinetic } \\
\text { constant }^{3}\end{array}$ & SE \\
\hline \multicolumn{3}{|l|}{ Galactose } \\
\hline $\mathrm{Gal}_{\max }(\mathrm{m} M)$ & 2.0 & 0.52 \\
\hline $\mathrm{R}_{\max , \text { Gal }}(\mu \mathrm{mol} / \mathrm{h})$ & 98.2 & 28.3 \\
\hline$\lambda_{\text {Gal }}(\mathrm{h})$ & 50.2 & 3.52 \\
\hline $\mathrm{Gal}_{0}(\mathrm{~m} M)$ & 2.6 & 0.13 \\
\hline$q_{\text {Gal }}\left(\mathrm{pmol} \times\right.$ net $\left.\mathrm{cfu}^{-1} \times \mathrm{h}^{-1}\right)$ & 0.353 & 0.0156 \\
\hline \multicolumn{3}{|l|}{ Lactose } \\
\hline $\mathrm{R}_{\max , \mathrm{Lac}}(\mu \mathrm{mol} / \mathrm{h})$ & 108.7 & 21.86 \\
\hline$\lambda_{\mathrm{Lac}}(\mathrm{h})$ & 37.3 & 1.78 \\
\hline $\operatorname{Lac}_{0}(\mathrm{~m} M)$ & 1.6 & 0.11 \\
\hline$q_{\text {Lac }}\left(\right.$ pmol $\times$ net $\left.\mathrm{cfu}^{-1} \times \mathrm{h}^{-1}\right)$ & 0.016 & 0.0036 \\
\hline \multicolumn{3}{|l|}{ Citrate } \\
\hline $\mathrm{R}_{\max , \mathrm{Cit}}(\mu \mathrm{mol} / \mathrm{h})$ & 171.3 & 29.71 \\
\hline$\lambda_{\text {Cit }}(\mathrm{h})$ & 46.5 & 1.83 \\
\hline $\mathrm{Cit}_{0}(\mathrm{~m} M)$ & 2.7 & 0.19 \\
\hline$q_{\text {Cit }}\left(\mathrm{pmol} \times\right.$ net $\left.\mathrm{cfu}^{-1} \times \mathrm{h}^{-1}\right)$ & 0.016 & 0.0035 \\
\hline
\end{tabular}

${ }^{1}$ Results represent the mean derived from triplicate experiments.

${ }^{2}$ Apparent maximum consumption rates of galactose, lactose, and citrate are designated as $R_{\text {max,Gal }}, R_{\text {max,Lac }}$ and $R_{\text {max,Cit }}$, respectively. The time when fermentation of galactose, lactose, and citrate were detected are designated $\lambda_{\text {Gal }}, \lambda_{\text {Lac }}$, and $\lambda_{\text {Cit }}$, respectively. The initial concentration of galactose, lactose, and citrate are designated $\mathrm{Gal}_{0}$, $\mathrm{Lac}_{0}$, and $\mathrm{Cit}_{0}$, respectively. The specific substrate consumption rate of galactose, lactose, and citrate are designated as $q_{\mathrm{Gal}}, q_{\mathrm{Lac}}$, and $q_{\mathrm{Cit}}$, respectively.

${ }^{3}$ Kinetic constants were calculated using an equation derived from the Gompertz model (Fan et al., 2004) and Logarithmic model (Görgens et al., 2005).

determined to be $0.335 \pm 0.0144(P<0.001)$ for galactose, $0.016 \pm 0.0036(P<0.001)$ for lactose, and 0.016 $\pm 0.0035(P<0.001)$ for citrate $\left(\mathrm{pmol} \times \mathrm{cfu}^{-1} \times \mathrm{h}^{-1}\right)$ (Figure 4). The specific consumption rates for galactose indicate that this substrate is used during the logarithmic growth phase $22 \pm 5$ times faster than lactose and citrate. Lactose and citrate are utilized at similar rates during exponential growth; however, the energy that these substrates produce during fermentation is 4 times higher for lactose than citrate. These very low amounts suggest that these substrates are not the main source of energy under the conditions of this study. In addition, a rate of $0.355 \mathrm{pmol} / \mathrm{cfu}$ during exponential growth for galactose is not enough to explain the final cell densities observed, indirectly suggesting that other substrates are being utilized or preferred during exponential growth.

\section{Phosphoserine and Phosphoserine-Containing Peptides}

The consumption pattern of the phosphoserine and phosphoserine-containing peptide mixture is presented in Figure 3. To determine consumption rates, Equation 5 was applied and results are summarized in Table
4. Utilization of the phosphoserine/phosphoserinecontaining peptide pool was initiated during early logarithmic growth of $L b$. paracasei ATCC 334 in CCE with an apparent consumption rate $\left(\mathrm{R}_{\max , S e r P, 1}\right)$ of 0.3 $\mathrm{mEq} / \mathrm{h}$, and levels decreased relatively rapidly until 2.2 $\mathrm{mEq}$ were consumed. Additionally, a second apparent maximum consumption rate $\left(\mathrm{R}_{\max , \mathrm{Ser}, 2}\right)$ of $0.1 \mathrm{mEq} / \mathrm{h}$ was observed once cells reached the stationary phase and continued until the end of the fermentation. The specific consumption rate for phosphoserine-containing phosphopeptides was estimated to be $0.016 \pm 0.0016$ ( $P$ $>0.001 ;$ pmol $\times \mathrm{cfu}^{-1} \times \mathrm{h}^{-1}$; see Figure 4), supporting the view that these biomolecules are not utilized during the logarithmic growth phase. These results suggest that phosphoserine/phosphoserine-containing peptide pool is utilized during both the logarithmic and stationary growth phases.

Smeianov et al. (2007) proposed a pathway for phosphoserine utilization in Lactobacillus helveticus CNRZ 32 , wherein phosphoserine is converted to 3-phosphohydroxypyruvate by phosphoserine aminotransferase (SerC), then to 3-phosphoglycerate, a glycolytic intermediate, by phosphoglycerate dehydrogenase (SerA). While the annotated genomic sequence of $L b$. paracasei ATCC 334 does contain serA, an ortholog to serC has not been detected. However, the genome encodes at least 8 different aminotransferases, and it is plausible that one or more of these enzymes is able to catalyze conversion of 3-phosphoserine to 3-phosphohydroxypyruvate.

\section{Kinetics of Product Biosynthesis}

Similar to substrate consumption and bacterial growth, the formation of aqueous products was analyzed using equations derived from the Gompertz model (Equations 5 and 6).

\section{Organic Acids}

L-Lactate was present at concentrations of $35.88 \pm$ $2.56,27.77 \pm 1.69$, and $28.65 \pm 1.04 \mathrm{mM}$ in $2 \mathrm{mCCE}$, $6 \mathrm{mCCE}$, and $8 \mathrm{mCCE}$, respectively. Similarly, total lactic acid was present in $2 \mathrm{mCCE}, 6 \mathrm{mCCE}$, and $8 \mathrm{mCCE}$ at concentration $\mathrm{s}$ of $36.2 \pm 2.56,28.2 \pm 1.70$, and $29.4 \pm 1.04 \mathrm{~m} M$, respectively. The observed decrease in total lactic acid of $8.5 \pm 3.08 \mathrm{~m} M$ between $\mathrm{CCE}$ prepared from cheese ripened for 2 and 6 mo suggests that lactate was metabolized into other products by the cheese microbiota during this time period. Previously, Thomas et al. (1985) determined that some pediococci are able to metabolize L-lactate to acetate and $\mathrm{CO}_{2}$ via an oxygen-dependent pathway. However, no pediococci were detected by denaturing gradient gel electropho- 

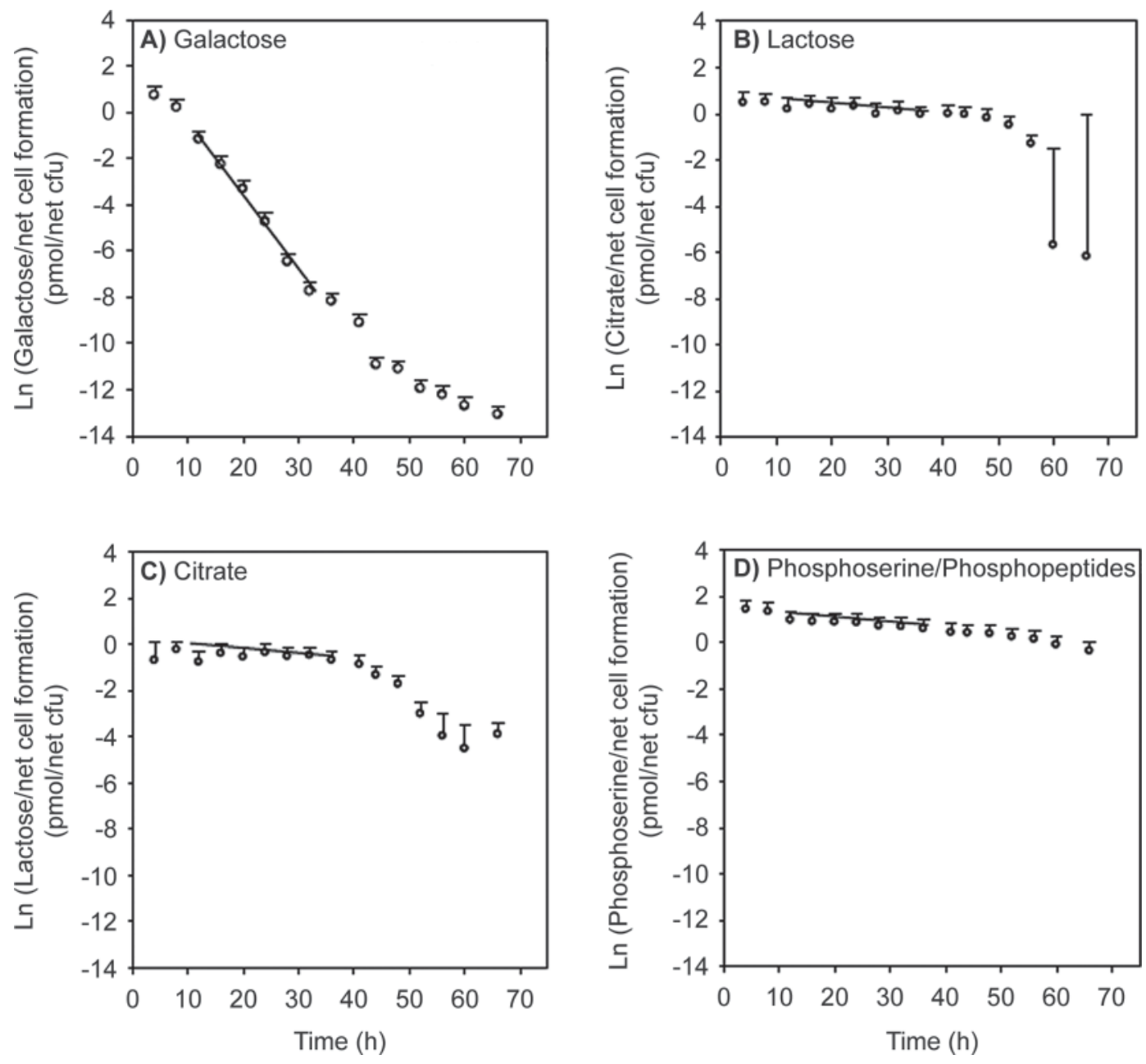

Figure 4. Relative concentrations of galactose (A), lactose (B), citrate (C), and phosphoserine-containing peptides (D) in Lactobacillus paracasei ATCC 334 fermentations in Cheddar cheese extract prepared from 2-mo-old cheese (2mCCE). Lines represent the specific substrate consumption rates obtained using the logarithmic method by nonlinear regression analysis. Bars represent the standard deviation of triplicate experiments and duplicate analysis.

resis (J. L. Steele and J. R. Broadbent, unpublished data). Therefore, it is possible that other LAB were present that were capable of metabolizing lactate during cheese ripening.

Formate, acetate, and D-lactate were produced during growth in $2 \mathrm{mCCE}, 6 \mathrm{mCCE}$, and $8 \mathrm{mCCE}$ (Table 2 ). The relatively high levels of L-lactate present in the $\mathrm{CCE}$, and the higher standard deviation observed ( $\sigma$ $=0.25 \mathrm{mM}$ ) during the fermentations prevented the estimation of its kinetic parameters, because no change greater than this standard deviation in L-lactate concentration was measured in any of the fermentations and, hence, these values are not presented in Table 2 . The primary L-lactate dehydrogenase of $L b$. paracasei is allosterically regulated by fructose-1,6-bisphosphate (FDP), reducing the enzyme's activity when FDP is at a low concentration. Hence, significant production of
L-lactate is not expected during growth in media with limiting carbohydrate, such as is present in CCE (de Vries et al., 1970; Viana et al., 2005). However, the $L b$. paracasei ATCC 334 genome contains 4 putative genes (LSEI0145, LSEI0634, LSEI1310, and LSEI2549) annotated as L-lactate dehydrogenases and 5 annotated as malate/L-lactate dehydrogenases ( LSEI131-, LSEI2866, LSEI0634, LSEI2549, and LSEI2607); hence, a low level of production or utilization of L-lactate may have occurred.

\section{Formate}

The amount of formate produced by $L b$. paracasei ATCC 334 during growth in $2 \mathrm{mCCE}, 6 \mathrm{mCCE}$, and $8 \mathrm{mCCE}$ was $5.4 \pm 0.27,4.8 \pm 0.19$, and $3.6 \pm 0.04 \mathrm{mM}$ (Table 2). Production of formate is likely the result 
Table 4. Kinetics of substrate consumption for phosphoserine/ phosphoserine-containing peptides during growth of Lactobacillus paracasei ATCC 334 at $37^{\circ} \mathrm{C}$ and $\mathrm{pH} 5.2$ in Cheddar cheese extract prepared from 2-mo-old cheese ${ }^{1}$

\begin{tabular}{|c|c|c|}
\hline Parameter $^{2}$ & $\begin{array}{l}\text { Kinetic } \\
\text { constant }^{3}\end{array}$ & SE \\
\hline \multicolumn{3}{|c|}{ First utilization of phosphoserine pool } \\
\hline $\operatorname{SerP}_{\max 1}(\mathrm{mEq})$ & 2.2 & 0.11 \\
\hline $\mathrm{R}_{\max , \operatorname{SerP}, 1}(\mathrm{mEq} / \mathrm{h})$ & 0.3 & 0.02 \\
\hline$\lambda_{\text {SerP1 }}(\mathrm{h})$ & 6.0 & 0.47 \\
\hline $\operatorname{SerP}_{01}(\mathrm{mEq})$ & 7.0 & 0.12 \\
\hline \multicolumn{3}{|c|}{ Second utilization of phosphoserine pool } \\
\hline $\operatorname{SerP}_{\max , 2}(\mathrm{mEq})$ & 2.3 & 0.53 \\
\hline $\mathrm{R}_{\max , \operatorname{SerP} .2}(\mathrm{mEq} / \mathrm{h})$ & 0.1 & 0.04 \\
\hline$\lambda_{\mathrm{SerP} 2}(\mathrm{~h})$ & 47.9 & 1.66 \\
\hline $\operatorname{SerP}_{02}(\mathrm{mEq})$ & 4.2 & 0.09 \\
\hline$q_{\mathrm{SerP}}\left(\mathrm{pmol} \times\right.$ net $\left.\mathrm{cfu}^{-1} \times \mathrm{h}^{-1}\right)$ & 0.016 & 0.0016 \\
\hline
\end{tabular}

${ }^{1}$ Results represent the mean derived from triplicate experiments.

${ }^{2}$ Apparent maximum consumption rates of phosphoserine-containing peptides during first and second utilization periods are designated as $R_{\max , S e r P, 1}$ and $R_{\max , S e r P, 2}$, respectively. The time when phosphoserinecontaining peptides are beginning to be consumed during first and second utilization periods are designated $\lambda_{\mathrm{SerP} 1}$ and $\lambda_{\mathrm{SerP} 2}$, respectively. The initial concentration of phosphoserine-containing peptides before first and second utilization periods are designated $\operatorname{SerP}_{01}$ and $\operatorname{SerP}_{02}$, respectively. The specific substrate consumption rate of phosphoserine-containing peptides is designated as $q_{\mathrm{SerP}}$.

${ }^{3}$ Kinetic constants were calculated using an equation derived from the Gompertz model (Fan et al., 2004) and Logarithmic model (Görgens et al., 2005).

of pyruvate formate lyase activity on pyruvate and a gene encoding this activity has been identified in the Lb. paracasei ATCC 334 genome. The level of formate produced is likely to be higher than the level detected, as formate tends to evaporate faster than other organic acids due to its lower vapor pressure and likely to be lost by to the continuous flushing of the medium with an anaerobic gas mixture. Additionally, it is possible that the formate produced could have been further metabolized to $\mathrm{CO}_{2}$ and $\mathrm{H}_{2}$; however, a gene encoding the enzyme responsible for this reaction, formate dehydrogenase, has not been identified in the ATCC 334 genome.

\section{Acetate}

The amount of acetate produced by $L b$. paracasei ATCC 334 during growth in $2 \mathrm{mCCE}, 6 \mathrm{mCCE}$, and $8 \mathrm{mCCE}$ was $7.5 \pm 0.51,5.5 \pm 0.22$, and $5.0 \pm 0.07 \mathrm{mM}$, respectively (Table 2). Several metabolic pathways can result in the formation of acetate; these include the pyruvate formate lyase- or acetyl-transferring dehydrogenase-initiated pathway, pentose metabolism, citrate utilization, and fatty acid degradation pathways. In the case of acetate formed during growth in $2 \mathrm{mCCE}$, previous research suggested that both pyruvate for- mate lyase and citrate utilization pathways are likely involved. Díaz-Muñiz and Steele (2006) demonstrated that $L b$. paracasei ATCC 334 produces approximately 2 mol of acetate for every mole of citrate consumed when grown with a limiting concentration of galactose. Therefore, metabolism of $2.3 \mathrm{~m} M$ citrate present in $2 \mathrm{mCCE}$ likely resulted in the accumulation of $4.6 \mathrm{mM}$ acetate. The parameters obtained from the application of the Gompertz model on substrate consumption and product biosynthesis (Tables 2 and 4) indicate that as citrate starts to be utilized, acetate began to be produced $(46.5 \pm 1.8 \mathrm{~h}$ for citrate utilization and $46.3 \pm$ $0.4 \mathrm{~h}$ for acetate production) and the maximum rate of acetate biosynthesis is 3.3 times higher than the rate of citrate utilization $(171.3 \pm 29.7$ and $569.5 \pm 46.6$ $\mu \mathrm{mol} / \mathrm{h}$, respectively), confirming a close relationship between citrate utilization and acetate formation. Limited information is available to form a hypothesis on the metabolic pathway(s) involved in the formation of acetate by $L b$. paracasei ATCC 334 during growth in $6 \mathrm{mCCE}$ and $8 \mathrm{mCCE}$. However, it is likely that these $\mathrm{CCE}$ contain very low levels of readily utilizable substrates and, hence, flux through the pyruvate formate lyase- or acetyl-transferring dehydrogenase-initiated pathway is likely responsible for a significant amount of the acetate produced during these fermentations.

\section{D-Lactate}

The amount of D-lactate produced by $L b$. paracasei ATCC 334 during growth in $2 \mathrm{mCCE}, 6 \mathrm{mCCE}$, and $8 \mathrm{mCCE}$ was $1.2 \pm 0.14,0.8 \pm 0.19$, and $0.1 \pm 0.02$ $\mathrm{m} M$, respectively (Table 2). The formation of D-lactate by $L b$. paracasei ATCC 334 during growth on limiting carbohydrate with or without addition of citrate was reported by Díaz-Muñiz et al. (2006). The D-lactate produced is likely the result of a fructose diphosphateindependent D-lactate dehydrogenase (Garvie, 1980). At least 2 such dehydrogenases have been identified in the Lb. paracasei ATCC 334 genome. Studies done on strain BL23 have demonstrated residual D-lactate dehydrogenase activity in $L b$. paracasei strains with inactivated lactate dehydrogenase genes, including hicD (Rico et al., 2008). The differences in the amounts of D-lactate produced between the different CCE is likely due to differences in final cell densities, substrates utilized, and relative flux through the competing pyruvate catabolic pathways.

\section{Kinetic Analysis of Organic Acid Formation}

The kinetic parameters obtained for acetate, formate and D-lactate production in $2 \mathrm{mCCE}, 6 \mathrm{mCCE}$, and $8 \mathrm{mCCE}$ using the Gompertz product formation 
Table 5. Volatiles produced (in relative abundance units) by Lactobacillus paracasei ATCC 334 at $37^{\circ} \mathrm{C}$ and $\mathrm{pH} 5.2$ during growth in Cheddar cheese extract prepared from 8-mo-old cheese ${ }^{1}$

\begin{tabular}{|c|c|c|c|c|c|c|c|}
\hline \multirow[b]{2}{*}{ Precursor $^{2}$} & \multirow[b]{2}{*}{ Compound } & \multicolumn{6}{|c|}{ Fermentation time } \\
\hline & & $0 \mathrm{~h}$ & $7 \mathrm{~h}$ & $24 \mathrm{~h}$ & $36 \mathrm{~h}$ & $64 \mathrm{~h}$ & $72 \mathrm{~h}$ \\
\hline PYR, AC & Ethanol & 20.6 & 86.1 & 148 & 128 & 120 & 1,624 \\
\hline PYR & Diacetyl & 1.35 & 3.68 & 2.53 & 2.03 & 2.07 & 1.40 \\
\hline PYR & Acetoin & 0.92 & 1.21 & 1.37 & 1.09 & 1.15 & 1.38 \\
\hline PYR & Formate & - & - & - & 0.28 & 0.48 & 0.69 \\
\hline $\mathrm{AC}$ & Hexanal & 0.67 & 1.42 & - & - & - & - \\
\hline $\mathrm{AC}$ & 1-Hexanol & - & 0.42 & 0.46 & 0.43 & 0.43 & - \\
\hline $\mathrm{AC}$ & Acetate & 5.60 & 6.73 & 7.64 & 12.47 & 43.94 & 59.82 \\
\hline $\mathrm{AC}$ & 1-Butanol & 0.40 & 0.46 & 0.49 & 0.42 & 0.61 & 0.55 \\
\hline $\mathrm{AC}$ & Butyrate & 1.36 & 2.46 & 2.28 & 2.14 & 2.95 & 3.47 \\
\hline AA & Propanal & 0.61 & 2.01 & - & - & - & - \\
\hline AA & 2-Butanone & - & 3.57 & 1.90 & 0.98 & - & 1.48 \\
\hline UNK & 2-Ethyl-1-hexanol & - & - & - & 0.46 & - & 0.55 \\
\hline UNK & Ethyl ether & 2.92 & 4.00 & 4.82 & 5.21 & 3.77 & 4.27 \\
\hline
\end{tabular}

${ }^{1}$ Results represent the mean derived from triplicate experiments.

${ }^{2}$ Possible precursors: $\mathrm{PYR}=$ pyruvate; $\mathrm{AC}=$ acetyl-coenzyme $\mathrm{A}(\mathrm{CoA}) ;$ and $\mathrm{UNK}=$ unknown.

equations are presented in Table 2. The lag time decreased for acetate and formate formation as the age of cheese used for CCE preparation increased, suggesting an earlier switch to pathways forming products other than lactic acid (e.g., pyruvate formate lyase pathway, pentose phosphate pathway, and phosphoketolase pathway). The lag time for D-lactate formation remained the same. The rate of production of acetate, formate and D-lactate decreases as the age of cheese used in the preparation of CCE increases, likely due to slower growth rates in these CCE. The molar ratios of formate to D-lactate were significantly higher in $8 \mathrm{mCCE}$ $(27.8 \pm 4.78 ; P<0.01)$ compared with the ratios found in $2 \mathrm{mCCE}$ and $6 \mathrm{mCCE}(4.3 \pm 0.55$ and $5.8 \pm 1.27$, respectively). This suggests that flux through the pyruvate formate lyase pathway is favored over the activity of D-lactate dehydrogenase during growth in $8 \mathrm{mCCE}$.

\section{Appearance of Volatile Compounds in $8 \mathrm{mCCE}$}

Attempts were made to capture volatiles produced during fermentation of $2 \mathrm{mCCE}$ and $6 \mathrm{mCCE}$ using sorbent cartridges. Unfortunately, the use of continuous gas flow during fermentation washed out the volatile adsorbed by these cartridges. Hence, volatile data was only available via solid-phase microextraction analyses from 5 time points during the $8 \mathrm{mCCE}$ fermentation (Table 5). In general, alcohols, aldehydes, ketones, and organic acids were produced during the fermentation of carbohydrates present in CCE by $L b$. paracasei ATCC 334.

The volatiles produced during growth in a carbohydrate-limited environment is a reflection of the microbiota optimizing energy formation, while maintaining its NAD+/NADH balance. Ethanol was the volatile produced in the greatest quantity and the most likely source of ethanol biosynthesis is via acetaldehyde dehydrogenase activity on acetaldehyde (Supplemental Figure S1, Panel A and B; available online at http://www. journalofdairyscience.org). Acetaldehyde can be either formed directly from pyruvate via pyruvate decarboxylase (Supplemental Figure S1, Panel A) or indirectly from acetyl-coenzyme A (CoA) formed from pyruvate by pyruvate formate lyase or an acetyl-transferring pyruvate dehydrogenase. Acetaldehyde would then be formed from acetyl-CoA by the sequential activities of an NADH-dependent acetaldehyde dehydrogenase and NADH-dependent alcohol dehydrogenase (Supplemental Figure S1, Panel B; available online at http://www. journalofdairyscience.org). Depending on the pathway used, either 1 or 2 molecules of $\mathrm{NAD}(\mathrm{P})+$ is regenerated per molecule of ethanol produced. The formation of acetate in $8 \mathrm{mCCE}$, which lacks citrate, is likely due to conversion of pyruvate to acetyl-CoA by either pyruvate formate lyase or an acetyl-transferring pyruvate dehydrogenase with the acetyl-CoA formed converted to acetate by the sequential activity of phosphate acetyltransferase and acetate kinase. This pathway results 
in the formation of 1 mol each of acetate and ATP from 1 mol each of pyruvate and ADP.

In addition to the primary carbon flux described above, the volatile compounds produced by $L b$. paracasei ATCC 334 during growth in $8 \mathrm{mCCE}$ suggest a variety of other relatively minor metabolic fluxes. Volatiles such as 2-butanone, benzaldehyde, and 3-methyl butanal are likely products of AA catabolic pathways. Diacetyl (2,3-butanedione) and acetoin (3-hydroxy2-butanone) are thought to arise from the activity of acetolactate synthase on pyruvate. Acetaldehyde, acetone, butanol, and butanoate (butyrate) are likely formed via acetyl-CoA metabolic pathways (Supplemental Figure S1, panel B; available online at http://www. journalofdairyscience.org). It is interesting to note that some compounds accumulate during earlier times in the fermentation and then decrease in concentration. The majority of these compounds exhibiting this pattern are substrates for dehydrogenases (i.e., acetaldehyde, diacetyl, hexanal, 2-butanone, and benzaldehyde) and, hence, likely play an important role in maintaining the $\mathrm{NAD}+/ \mathrm{NADH}$ balance. The volatiles produced during the growth of $L b$. paracasei ATCC 334 in $8 \mathrm{mCCE}$ can be directly related to flux through pyruvate, acetylCoA, or AA catabolic pathways. The need to generate energy, while maintaining NAD+/NADH balance, likely dictates the fluxes through these pathways.

\section{Metabolic Fluxes in 2mCCE}

The substrates utilized during growth of $L b$. paracasei ATCC 334 in 2mCCE were phosphopeptides, lactose, galactose, and citrate. The primary metabolic end products observed were D-lactate, formate, and acetate. The amounts of substrates were $1.70 \mathrm{mmol}$ of lactose, $2.83 \mathrm{mmol}$ of galactose (however, only 1.76 $\pm 0.10 \mathrm{mmol}$ were used), and $2.91 \mathrm{mmol}$ of citrate, whereas the amounts of products detected were 7.53 mmol of acetate, $5.35 \mathrm{mmol}$ of formate, and $1.24 \mathrm{mmol}$ D-lactate. The metabolism of $1 \mathrm{~mol}$ of citrate by $L b . c a$ sei ATCC 334 in CCE results in the formation of $1 \mathrm{~mol}$ of acetate, $1 \mathrm{~mol}$ of L-lactate, and $1 \mathrm{~mol}$ of $\mathrm{CO}_{2}$ (DíazMuñiz and Steele, 2006). Therefore, the metabolism of $2.91 \mathrm{mmol}$ of citrate is expected to yield $2.91 \mathrm{mmol}$ of acetate, $2.91 \mathrm{mmol}$ of L-lactate, and $2.91 \mathrm{mmol}$ of $\mathrm{CO}_{2}$, leaving $4.62 \mathrm{mmol}$ of additional acetate to account for. The $1.70 \mathrm{mmol}$ of lactose and $1.76 \mathrm{mmol}$ of galactose (5.16 mmol of hexoses) are most likely metabolized via the Embden-Meyerhoff pathway to yield $10.32 \mathrm{mmol}$ of pyruvate, which can be further metabolized by a variety of pathways. The production of $1.24 \mathrm{mmol}$ of D-lactate via a fructose diphosphate-independent dehydrogenase would account for $1.24 \mathrm{mmol}$ of pyruvate, and production of $5.35 \mathrm{mmol}$ of formate and $5.35 \mathrm{mmol}$ of acetyl-CoA via a pyruvate formate lyase would still leave $3.73 \mathrm{mmol}$ of pyruvate unaccounted for. Several explanations can account for the remaining pyruvate; the incomplete recovery of formate results in underestimating the contribution of pyruvate formate lyase, or the activity of other enzymes active on pyruvate, such as acetyl-transferring pyruvate dehydrogenase, pyruvate decarboxylase, or acetolactate synthase. The conversion of $4.62 \mathrm{mmol}$ of acetyl-CoA to acetate would generate $4.62 \mathrm{mmol}$ of ATP and account for the remainder of the acetate observed. The remaining $0.73 \mathrm{mmol}$ of acetyl-CoA could be converted into ethanol, acetone, butanol, and butyrate. It is important to note that the production of either ethanol or 2,3-butanediol would regenerate $2 \mathrm{mmol}$ of $\mathrm{NAD}(\mathrm{P})+$ and, hence, these pathways likely have an important role in maintaining redox balance. These results suggest that citrate is converted to acetate as described previously by DíazMuñiz et al. (2006), whereas lactose and galactose are utilized via the Embden-Meyerhoff pathway to produce pyruvate, which is subsequently converted to formate, acetate, and D-lactate. A portion of the pyruvate pool formed could not be accounted for; likely, additional end products derived from this pool include ethanol, 2,3-butanediol, acetone, butanol, and butyrate.

The production of volatiles during growth of $L b . p a-$ racasei ATCC 334 in $8 \mathrm{mCCE}$ was monitored to evaluate the metabolic pathways utilized by $L b$. casei during the later stages of ripening Cheddar cheese. The 2 volatiles detected at high levels were ethanol and acetate, with ethanol being produced in the greatest quantity. Ethanol is most likely produced from acetaldehyde via acetaldehyde dehydrogenase and likely has a role in regenerating $\mathrm{NAD}+$. Acetate is the volatile formed in the second greatest amount; in $8 \mathrm{mCCE}$, it is most likely formed through sequential activity of either pyruvate formate lyase or an acetyl-transferring pyruvate dehydrogenase to generate acetyl-CoA, with the acetyl-Coa subsequently being metabolized by phosphate acetyltransferase and acetate kinase to generate acetate and ATP. The remaining detected volatiles are present in significantly lower amounts and likely result from either AA catabolism or relatively minor fluxes from pyruvate or acetyl-CoA metabolism. The organism's need to generate energy, while maintaining $\mathrm{NAD}+/ \mathrm{NADH}$ balance, dictates fluxes through these pathways and, hence, cheese flavor development.

\section{Metabolic Fluxes in 6mCCE and 8mCCE}

Analyses of $6 \mathrm{mCCE}$ and $8 \mathrm{mCCE}$ fermentation determined that the level of galactose, lactose, citrate, and phosphoserine/phosphoserine-containing peptides were all below their quantifiable levels of $0.22 \mathrm{~m} M, 0.19 \mathrm{mM}$, 
$0.02 \mathrm{mM}$, and $0.10 \mathrm{mEq}$, respectively. Using a carbonbalancing approach and assuming each substrate is at its limit of detection, in total, these substrates could result in the formation of $1.32 \mathrm{~m} M$ pyruvate. However, growth of Lb. paracasei ATCC 334 in 6mCCE resulted in the production of $5.50 \pm 0.22,0.85 \pm 0.19$, and $4.82 \pm$ $0.19 \mathrm{~m} M$ acetate, D-lactate, and formate, respectively, whereas growth of $L b$. paracasei ATCC 334 in $8 \mathrm{mCCE}$ resulted in the production of $5.01 \pm 0.07,0.13 \pm 0.02$, and $3.61 \pm 0.04 \mathrm{mM}$ acetate, D-lactate, and formate, respectively. By conducting a simple carbon balance it is possible to calculate that 6.10 and $2.96 \mathrm{~m} M$ pyruvate would be required to produce the observed products in $6 \mathrm{mCCE}$ and $8 \mathrm{mCCE}$, respectively. This analysis strongly suggests that substrates other than galactose, lactose, citrate, and phosphoserine/phosphoserinecontaining peptides are utilized during growth of $L b$. paracasei ATCC334 in 6mCCE and 8mCCE.

\section{CONCLUSIONS}

A more detailed understanding of substrates utilized for growth, the metabolic pathways employed, and how flux through these pathways is controlled is required to control the effect of NSLAB on cheese flavor development. The development of CCE, a model medium based upon the aqueous phase of ripening Cheddar cheese, has allowed us to begin to probe the growth characteristics, substrates that support growth, as well as the metabolic pathways utilized and products formed by a representative NSLAB, Lb. paracasei ATCC 334, during growth in ripening Cheddar cheese. To assess the changes in substrates present as a function of ripening time, $2 \mathrm{mCCE}$, $6 \mathrm{mCCE}$, and $8 \mathrm{mCCE}$ were prepared. Results demonstrated that the ability of CCE to support the growth of $L b$. paracasei decreased as the ripening time of the Cheddar cheese used to prepare this medium increased. However, even $8 \mathrm{mCCE}$ contained sufficient growth substrates for ATCC 334 to reach a final cell density of 2.1 $\times 10^{7} \mathrm{cfu} / \mathrm{mL}$. This result suggests that substrate availability does not limit growth of $L b$. paracasei in cheese aged up to $8 \mathrm{mo}$, even though lactose, galactose, and citrate, known growth substrates for this species, were only detected in 2mCCE. Additionally, the metabolic products formed by $L b$. paracasei ATCC 334 during growth in $6 \mathrm{mCCE}$ and $8 \mathrm{mCCE}$ cannot be explained by the residual levels of lactose, galactose, and citrate present in theses CCE, suggesting that additional energy sources (i.e., milk-derived complex carbohydrates and starter-derived components) are utilized during growth of $L b$. paracasei ATCC 334 in these CCE. Research to identify the growth substrates utilized by $L b$. paracasei and other NSLAB after the simple carbohydrates and citrate are exhausted, or at concentrations below BQL, is underway in our laboratories.

\section{ACKNOWLEDGMENTS}

This research was supported by Dairy Management Inc., through the Center for Dairy Research (Madison, WI) and Western Dairy Center (Logan, UT), as well as by the National Institute of Food and Agriculture, United States Department of Agriculture (Washington, DC), under ID number WISO1347. Peggy Steele, a member of J. L. Steele's family, is employed by Danisco Inc. (Madison, WI), a supplier of bacterial cultures to the food industry.

\section{REFERENCES}

Adamberg, K., M. Antonsson, F. K. Vogensen, E. W. Nielsen, S. Kask, P. L. Møller, and Y. Ardö. 2005. Fermentation of carbohydrates from cheese sources by non-starter lactic acid bacteria isolated from semi-hard Danish cheese. Int. Dairy J. 15:873-882.

Adamberg, K., S. Kask, T.-M. Laht, and T. Paalme. 2003. The effect of temperature and $\mathrm{pH}$ on the growth of lactic acid bacteria: A pH-auxostat study. Int. J. Food Microbiol. 85:171-183.

Axelsson, L. 2004. Lactic acid bacteria: Classification and physiology. Pages 1-66 in Lactic Acid Bacteria: Microbiology and Functional Aspects. S. Salminen, A. von Wright, and A. Ouwehand, ed. Marcel Dekker, New York, NY.

Broadbent, J. R., K. Houck, M. E. Johnson, and C. J. Oberg. 2003 Influence of adjunct use and cheese microenvironment on nonstarter bacteria in reduced-fat Cheddar-type cheese. J. Dairy Sci. 86:2773-2782.

de Vries, W., W. M. C. Kapteijn, E. G. van der Beek, and A. H. Stouthamer. 1970. Molar growth yields and fermentation balances of Lactobacillus casei $\mathrm{L}_{3}$ in batch cultures and in continuous cultures. J. Gen. Microbiol. 63:333-345.

Díaz-Muñiz, I., D. S. Banavara, M. F. Budinich, S. A. Rankin, E. G. Dudley, and J. L. Steele. 2006. Lactobacillus casei metabolic potential to utilize citrate as an energy source in ripening cheese: A bioinformatics approach. J. Appl. Microbiol. 101:872-882.

Díaz-Muñiz, I., and J. L. Steele. 2006. Conditions required for citrate utilization during growth of Lactobacillus casei ATCC334 in chemically defined medium and cheddar cheese extract. Antonie van Leeuwenhoek 90:233-243.

Fan, Y., Y. Wang, P.-Y. Qian, and J.-D. Gu. 2004. Optimization of phthalic acid batch biodegradation and the use of modified Richards model for modelling degradation. International Biodeterioration and Biodegradation 53:57-63.

Farrar, G. H., and R. Harrison. 1978. Isolation and structural characterization of alkali-labile oligosaccharides from bovine milk-fatglobule membrane. Biochem. J. 171:549-557.

Fernández, M., and M. Zuniga. 2006. Amino acid catabolic pathways of lactic acid bacteria. Crit. Rev. Microbiol. 32:155-183.

Fiat, A.-M., C. Alais, and P. Jollès. 1972. The amino-acid and carbohydrate sequences of a short glycopeptide isolated from bovine к-casein. Eur. J. Biochem. 27:408-412.

Foucaud, C., and B. Poolman. 1992. Lactose transport system of Streptococcus thermophilus. Functional reconstitution of the protein and characterization of the kinetic mechanism of transport. J. Biol. Chem. 267:22087-22094.

Galesloot, T. E. 1960. The oxidation-reduction potential of Cheese. Neth. Milk Dairy J. 14:111-140.

Galesloot, T. E., and J. S. Kooy. 1960. The oxidation-reduction potential of starter and milk inoculated with starter. Neth. Milk Dairy J. $14: 1-22$. 
Garvie, E. I. 1980. Bacterial lactate dehydrogenases. Microbiol. Rev. 44:106-139.

Görgens, J. F., W. H. Van Zyl, and J. H. Knoetze. 2005. Reliability of methods for the determination of specific substrate consumption rates in batch culture. Biochem. Eng. J. 25:109-112.

Harlow, E., and D. Lane. 1988. Antibodies: A Laboratory Manual. Cold Spring Harbor Laboratory, Cold Spring Harbor, NY.

Hassan, A., M. E. Johnson, and J. A. Lucey. 2004. Changes in the proportions of soluble and insoluble calcium during the ripening of Cheddar cheese. J. Dairy Sci. 87:854-862.

Johnson, M. E., B. A. Riesterer, and N. F. Olsen. 1990. Influence of nonstarter bacteria on calcium lactate crystallization on the surface of Cheddar cheese. J. Dairy Sci. 73:1145-1149.

Johnson, M. E., and J. L. Steele. 2008. Fermented dairy products. Pages 767-781 in Food Microbiology: Fundamentals and Frontiers. 3rd ed. M. P. Doyle and L. R. Beuchat, ed. American Society for Microbiology (ASM) Press, Washington, DC.

Judicial Commission of the International Committee on Systematics of Bacteria. 2008. The type strain of Lactobacillus casei is ATCC 393. ATCC 334 cannot serve as the type because it represents a different taxon, the name Lactobacillus paracasei and its subspecies names are not rejected and the revival of the name 'Lactobacillus zeae' contravenes Rules 51b (1) and (2) of the International Code of Nomenclature of Bacteria. Opinion 82. Int. J. Syst. Evol. Microbiol. 58:1764-1765.

Kieronczyk, A., S. Skeie, K. Olsen, and T. Langsrud. 2001. Metabolism of amino acids by resting cells of non-starter lactobacilli in relation to flavour development in cheese. Int. Dairy J. 11:217-224.

Kim, D. H., C. Kanno, and Y. Mizokami. 1992. Purification and characterization of major glycoproteins, PAS-6 and PAS-7, from bovine milk fat globule membrane. Biochim. Biophys. Acta 1122:203-211.

Kovárová-Kovar, K., and T. Egli. 1998. Growth kinetics of suspended microbial cells: From single-substrate-controlled growth to mixedsubstrate kinetics. Microbiol. Mol. Biol. Rev. 62:646-666.

Kristoffersen, T. 1967. Interrelationships of flavor and chemical changes in cheese. J. Dairy Sci. 50:279-284.

Lee, M. R., M. E. Johnson, and J. A. Lucey. 2005. Impact of modifications in acid development on the insoluble calcium content and rheological properties of Cheddar cheese. J. Dairy Sci. 88:37983809 .

Lendenmann, U., and T. Egli. 1998. Kinetic models for the growth of Escherichia coli with mixtures of sugars under carbon-limited conditions. Biotechnol. Bioeng. 59:99-107.

Marilley, L., and M. G. Casey. 2004. Flavours of cheese products: Metabolic pathways, analytical tools and identification of producing strains. Int. J. Food Microbiol. 90:139-159.

Martín-Sosa, S., M.-J. Martín, L.-A. García-Pardo, and P. Hueso. 2003. Sialyloligosaccharides in human and bovine milk and in infant formulas: Variations with the progression of lactation. J. Dairy Sci. 86:52-59.

Mather, I. H. 2000. A review and proposed nomenclature for major proteins of the milk-fat globule membrane. J. Dairy Sci. 83:203247.
Mauriello, G., L. Moio, G. Moschetti, P. Piombino, F. Addeo, and S. Coppola. 2001. Characterization of lactic acid bacteria strains on the basis of neutral volatile compounds produced in whey. J. Appl. Microbiol. 90:928-942.

Neeser, J.-R., M. Golliard, and S. Del Vedovo. 1991. Quantitative determination of complex carbohydrates in bovine milk and in milkbased infant formulas. J. Dairy Sci. 74:2860-2871.

Rankin, S. A. 2001. Solvent desorption dynamic headspace sampling of fermented dairy product volatiles. Adv. Exp. Med. Biol. 488:151163

Rankin, S. A., F. W. Bodyfelt, L. Chen, and E. Boyle-Roden. 1998 Solvent desorption dynamic headspace sampling of fermented dairy product volatiles. Page AGFD171 in Proc. 216th ACS National Meeting, Boston, MA. Am. Chem. Soc., Washington, DC

Rico, J., M. J. Yebra, G. Pérez-Martínez, J. Deutscher, and V. Monedero. 2008. Analysis of $l d h$ genes in Lactobacillus casei BL23: Role on lactic acid production. J. Ind. Microbiol. Biotechnol. 35:579-586.

Seefeldt, K. E., and B. C. Weimer. 2000. Diversity of sulfur compound production in lactic acid bacteria. J. Dairy Sci. 83:2740-2746.

Shah, N. P. 2000. Probiotic bacteria: Selective enumeration and survival in dairy foods. J. Dairy Sci. 83:894-907.

Singh, T. K., M. A. Drake, and K. R. Cadwallader. 2003. Flavor of Cheddar cheese: A chemical and sensory perspective. Compr. Rev. Food Sci. Food Safety 2:166-189.

Smeianov, V. V., P. Wechter, J. R. Broadbent, J. E. Hughes, B. T. Rodríguez, T. K. Christensen, Y. Ardö, and J. L. Steele. 2007. Comparative high-density microarray analysis of gene expression during growth of Lactobacillus helveticus in milk versus rich culture medium. Appl. Environ. Microbiol. 73:2661-2672.

Swearingen, P. A., D. J. O'Sullivan, and J. J. Warthesen. 2001. Isolation, characterization, and influence of native nonstarter lactic acid bacteria on Cheddar cheese quality. J. Dairy Sci. 84:50-59.

Thomas, T. D. 1987. Cannibalism among bacteria found in cheese. N.Z. J. Dairy Sci. Tech. 22:215-219.

Thomas, T. D., L. L. McKay, and H. A. Morris. 1985. Lactate metabolism by pediococci isolated from cheese. Appl. Environ. Microbiol. 49:908-913.

van Bodegom, P. 2007. Microbial maintenance: A critical review on its quantification. Microb. Ecol. 53:513-523.

Viana, R., M. J. Yebra, J. L. Galán, V. Monedero, and G. Pérez-Martínez. 2005. Pleiotropic effects of lactate dehydrogenase inactivation in Lactobacillus casei. Res. Microbiol. 156:641-649.

Weinrichter, B., H. Sollberger, W. Ginzinger, D. Jaros, and H. Rohm. 2004. Adjunct starter properties affect characteristic features of Swiss-type cheeses. Nahrung 48:73-79.

Zeng, A.-P., and W.-D. Deckwer. 1995. A kinetic model for substrate and energy consumption of microbial growth under substrate-sufficient conditions. Biotechnol. Prog. 11:71-79.

Zwietering, M. H., I. Jongenburger, F. M. Rombouts, and K. van 't Riet. 1990. Modeling of the bacterial growth curve. Appl. Environ. Microbiol. 56:1875-1881. 